\title{
FORUM
}

\author{
Invited article
}

DOI: http://dx.doi/10.12660/joscmv10n2p71-84

\section{THE EFFECT OF UNCERTAINTY AND COOPERATIVE BEHAVIOUR ON OPERATIONAL PERFORMANCE: EVIDENCE FROM BRAZILIAN FIRMS}

\begin{abstract}
This study aims to examine the effect of managers' uncertainty on cooperative behavior in interorganizational relationships, and how this affects operational performance. We conducted a survey with 225 Brazilian managers, and analyzed data using confirmatory factor analysis and structural equation modelling. Results present: a) a negative influence of uncertainty of state on operational performance; b) a positive influence of uncertainty of effect on uncertainty of response; c) a significant influence of uncertainty of response on cooperative behavior; and d) a positive influence of cooperative behavior on performance. The results indicated that cooperation and uncertainty accounted for $18.8 \%$ of the variability of operational performance. Considering the uncertainty that plagues Latin societies, this study can help to create more efficient ways to deal with the phenomenon. Rather than turning a blind eye to uncertainty, our study underscores it and treats it like another business environment issue.
\end{abstract}

KEYWORDS | Uncertainty, cooperative behavior, cooperation, operational performance, Brazilian firms.

\section{Eliane Pereira Zamith Brito eliane.brito@fgv.br}

Professor at Fundação Getulio Vargas, Escola de Administração de Empresas de São Paulo - São Paulo - SP, Brazil

Marta Fabiano Sambiase martafsambiase@gmail.com

Professor at Universidade Presbiteriana Mackenzie, Centro de Ciências Sociais e Aplicadas - São Paulo - SP, Brazil

Fernando Coelho Martins Ferreira fernando.coelho@fgv.br

Professor at Fundação Getulio Vargas, Escola de Administração de Empresas de São Paulo - São Paulo - SP, Brazil

\section{Adilson Aderito da Silva} adilson.silva@mackenzie.br

Professor at Universidade Presbiteriana Mackenzie, Centro de Ciências Sociais e Aplicadas - São Paulo - SP, Brazil 


\section{INTRODUCTION}

This paper aims to examine the effect of managers' perception of uncertainty on cooperative behavior in interorganizational relationships and how this behavior can influence organizational operational performance.

The initial inspiration for this study originates from Coase (1937 p. 6), who said that "the firm consists of a system of relationships", and Williamson (1985), through the contracts theory in the study of governance structures, particularly their hybrid form, as well as from the belief that when markets adopt competitive dynamics based on cooperative interorganizational relationships, the shared benefits are greater and more effective than when adopting the single view of competition based on inter-firm rivalry (Miles, Snow, \& Sharfman, 1993; Snow, Fjeldstad, Lettl \& Miles, 2011).

The degree of cooperation in interorganizational relationships can vary among agents, as can managers' uncertainty regarding the value generated by hybrid governance structures. This variation affects business results, and this can be observed in the firm's operational performance (White, 1996). Cooperation is not limited to people or organizations. Multilateral relationships with countries and trade blocs have become a common strategy of nations to foster social and economic prosperity. The closer relationship between Brazil and Argentina in the 1980's, leading to the later creation of Mercosur, is a widely known Latin American example of this new State policy. Since its creation, Brazilian foreign policy has kept itself tuned to all possibilities and challenges arising from this trade bloc, as well as to its relationship with many other organizations and neighboring countries (Vitale, 2016).

When it comes to uncertainty, its ubiquitous presence throughout companies' activities and endeavors is but the result of a large set of interactions with internal and external factors. Since uncertainty results when the outcome of a situation is not known or fixed (Johnson \& López-Alves, 2007), conceiving an uncertainty-free environment for a company or a person would sound rather naive, especially considering that the number and effect of these uncertainties change constantly over time.

In that respect, Latin America is no exception. Recent signs that the region is finally pulling out of recession after two years of contraction are challenged by uncertainties arising from policies of the new U.S. administration, besides the already known uncertainties deriving from endemic corruption and the culture of privilege in the region (World Economic Forum, 2017). As some Latin American countries still try to adjust their economies to the long-gone commodity boom cycle (2003 - 2010), which benefited South America in particular (Bello, 2017), uncertainties are considered greater than some time ago (Zewuster, 2017).

Microeconomic factors can also affect the level of uncertainty companies are subject to. Regional studies on this are almost nonexistent. The research conducted by Gonzáles, Guzmàn, Téllez and Trujillo (2016) is an exception worth mentioning. An analysis of over 3,000 company reports from the six largest Latin American countries showed that firms with better disclosure practices present superior market valuation and operating performance, and that uncertainty in the tone of information disclosed is negatively associated with higher firm valuation and better financial performance.

Particularly in Brazil, political uncertainty and delays in the country's economic reforms are also factors that hinder a stronger recovery (Sadler, 2017; Zewuster, 2017). The weak demand remains linked to uncertainty about future economic growth, due to political factors or structural economic limitations, such as low productivity and competitiveness levels, high public debt and its associated cost (ECLAC, 2017, p. 1).

The theoretical model of this study is based on Williamson (1985) and the relational view (Zajac \& Olsen, 1993; Dyer, 1997; Dyer \& Singh, 1998). The research hypotheses were tested by collecting data from 227 managers working in the Brazilian industrial sector. Data were analyzed using structural equation modelling (SEM) and the robust maximum likelihood (ML) estimation method (Finney \& Distefano, 2006). This technique allows researchers to simultaneously estimate multiple dependent relationships among latent variables, particularly when such variables influence a relationship (i.e., exogenous variables) and are influenced in subsequent relationships (i.e., endogenous variables) (Favero, Belfiore, Silva \& Chan, 2009). The latent constructs were validated using confirmatory factor analysis (CFA).

Results suggest the multidimensionality of the uncertainty construct, which is characterized by three uncertainties, namely uncertainty of state, effect, 
and response, according to Milliken $(1987,1990)$. The following findings had a 5\% level of statistical significance and a statistical power of $99.8 \%$ : a) uncertainty of state negatively influences operational performance; b) uncertainty of effect positively influences uncertainty of response; c) uncertainty of response significantly influences cooperative behavior; and d) cooperative behavior positively influences operational performance. As noted by the managers participating in this study, the results also indicated that uncertainty of state and cooperation accounted for $18.8 \%$ of the variability of operational performance, thus corroborating Dyer's findings in his studies of the relational view (Dyer, 1997; Dyer \& Singh, 1998).

\section{THEORETICAL BACKGROUND}

\section{Uncertainty}

The first approach to environmental uncertainty, dynamism, and complexity was proposed by economic scientists who long ago recognized that the differences between accessing information and handling its absence accounted for profitability differences among businesses (Knight, 2006; Williamson, 1985; Foss, 1996). The second approach originated from organizational theorists attempting to understand and explain the ways in which internal and external environments can interact as a prerequisite for satisfactory performance. This approach originated from Barnard (1938) and has subsequently appeared in the works of several authors (Lawrence \& Lorsch, 1967; Duncan, 1972; Pfeffer \& Salancik, 1977; Milliken, 1987; Kreiser \& Marino, 2002; Ashill, \& Jobber, 2009; Ghosh, Bhowmick \& Guin, 2014). As Lueg \& Borisov (2014, p. 658) summarize it, the approach "asserts that uncertainty stems from the relationship between the environment and the characteristics of executives".

Uncertainty is the pivot of Knight's profit theory; the connection between change and profit is uncertain and always indirect, and thus, uncertainty is the indirect connection between change and profit (Knight, 2006). Dynamic change leads to a particular form of revenue only if the change and its consequences are unpredictable because "it is this fact that change is a necessary condition of our being ignorant of the future that has given rise to the error that change is the cause of profit" (Knight, 2006, p.37). If all change occurred according to universal, invariable and well-known laws, then change would be predictable, and therefore, neither gain nor loss would occur (Milliken, 1987; LeRoy \& Singell, 1987; Langlois \& Cosgel, 1993).

Williamson proposes the Transaction Cost Economics (TCE) model based on the level of asset specificity involved in internal and external uncertainty. Internal uncertainty is the degree of difficulty in achieving performance. When there is ambiguity about performance, a firm cannot easily discern the level of performance it has achieved. Under high internal uncertainty, it is either not possible to establish outcome measures or possible to establish only poor measures; market choices would lead to high transaction costs because a firm would need to closely monitor and direct/guide the activity of independent firms. Thus, TCE predicts that firms will view the adoption of integrated governance options more favorably as internal uncertainty increases (Shervani, Frazier \& Challagala, 2007). Partners will not act opportunistically unless they are offered short-term incentives and uncertain long-term results (Bradach \& Eccles, 1989; Heide \& Stump, 1995; Choi, Lee, \& Kim, 1999). According to Williamson $(1975 ; 1985)$, opportunism considers the possibility of uncertainty in the other party's behavior, and most investment transactions are made under uncertain conditions.

External uncertainty is the extent to which it is difficult to predict future world events/states. A dynamic business environment that changes rapidly and/or is very complex drives this type of uncertainty. High external uncertainty, understood as the perceived interval/gap between expected outcomes and achieved outcomes, is associated with bounded rationality (Simon, 1983) and rigorous governance mechanisms based on contracts that specify most possible eventualities, when that is feasible (Eriksson \& Sharma, 2003; Gao, Sirgyb \& Birdb, 2005). Thus, facts' non-regularity can lead to asymmetric information and potential situations for external intermediary agents to act opportunistically. Amid high external uncertainty, transaction costs tend to be higher in the market because of the level of sophistication of contracts, alternatively directing toward higher levels of channel integration (Shervani et al., 2007).

In this study's empirical test, the operationalization of uncertainty was based on the multidimensionality of Milliken's (1987) proposed construct. Milliken defines uncertainty as an individual's perceived inability to make a prediction and suggests that the origin of uncertainty lies in the environment external the 
firm, on the same line of thought as Knight (2006). Milliken (1987) argues for the three-dimensionality of the uncertainty construct and classifies this factor in three types. The first type, state uncertainty, relates to the information available or believed to be available to a manager. The second type, effect uncertainty, is formed by the manager's cognitive processing of information about the environment. The third type, response uncertainty, relates to the manager's actions in response to the environment. The difference among the three types of uncertainty is the type of information that the manager/administrator perceives to be lacking. Sambiase-Lombardi and Brito (2010) and Ghosh et al. (2014) have already tested the uncertainty construct based on Milliken's proposal. In this context, the following four operationally viable hypotheses are presented below and in Figure 1.

H1 - State uncertainty influences effect uncertainty.

H2 - Effect uncertainty influences response uncertainty.

H3 - Response uncertainty influences the degree of cooperation.

H4 - State uncertainty influences business operational performance.

\section{Cooperation}

Numerous definitions of cooperation focus on the process through which individuals, groups, and organizations interact and form psychological relationships for mutual gain or benefit (Smith, Carrol \& Ashford, 1995). In addition, a significant number of studies consider the antecedents or effects of cooperation but do not define or measure the construct itself.

Organization theory defines cooperation in terms of voluntary joint activities or programs among a set of parties (Heide \& Miner, 1992), allowing for variations in the degree of interaction formality or intensity (Contractor \& Lorange, 1988; Cheng \& Tang, 2014). Ring and Van de Ven (1994, p. 96) define cooperation dynamically by including individuals' willingness to maintain cooperative relationships; these researchers note that cooperative relationships are "social mechanisms for collective actions, continually shaped and restructured by actions and symbolic interpretations of the parties involved". Cooperation is determined by self-interest, whereas reciprocity based on common goals is important in interorgani- zational relationships (Zajac \& Olsen, 1993). In the absence of social norms regulating the relationship, this may require developing incentives that can produce a selfish interest (Macneil, 1981), as explained by the expected utility hypothesis from game theory (Luce \& Raiffa, 1957/2013).

According to Smith et al. (1995), the type of cooperation can also vary according to how the different parties are connected to each other. Vertically linked individuals, groups, and organizations can cooperate with each other, as can individuals, groups, and organizations horizontally linked. When reciprocated, activities of this kind become favor exchanges. Nguyen and Cragg (2012) described favor exchange in informal cooperative behavior in business relationships as ethically questionable; in this study, the authors focused on its positive role and identified it as an ethical, functional behavior (Heide \& Miner, 1992).

Based on the original concept of transactions formulated by Commons, Ring and Van de Ven (1994) and Doz (1996) proposed a group of heuristics to explain the development and evolution of a cooperative relationship consisting of a repetitive sequence of negotiations, compromises and execution stages; each of these stages is evaluated in terms of efficiency and equity. Parkhe (1993) believes that a cooperative behavior among alliance partners can attenuate the opportunism that hinders the alliance's performance. The duration of each stage varies according to the uncertainty of the concepts involved, the trust between the parties and the relationship between the roles of the parties. These authors suggest that to sustain a business agreement, it may be necessary to maintain a cooperative relationship in the long term.

Among the theoretical approaches that allow describing cooperation are exchange theories, which define cooperation as a means of maximizing economical and psychological benefits (Blau, 1974; Nguyen \& Cragg, 2012). The parties involved in a relationship are willing to cooperate when the benefits of cooperating outweigh the costs. Exchange theories can be used appropriately to explain conscious and calculated reasons why the parties involved should cooperate among themselves and maintain cooperative relationships. Social structure theories provide a different perspective for cooperation, emphasizing the role of structural factors in providing cooperation (Blau, 1974). More specifically, structural theories aim to explain the emergence of cooperative relationships in terms of the aggregated conditions 
of the system in which such cooperation occurs. In line with modelling theories, social structure theories aim to measure/quantify a relationship to examine cooperation and coordination (Brito \& Mariotto, 2013). Thus, the fifth operationally viable hypothesis is presented as follows:

H5- Interorganizational cooperation influences business operational performance.

Heide and Miner (1992) suggest that cooperation is a phenomenon that manifests itself in different ways or behaviors. The researchers identify these four cooperative behaviors that can represent cooperation: flexibility in problem solving, information exchange, joint problem solving, and a restrictive use of power. According to the authors, these behaviors are not indicators of one single construct but, rather, possible ways to cooperate. Therefore, a greater number of cooperative behaviors adopted by an organization will lead to a higher intensity of these behaviors and thus, more cooperation (and vice versa).

In the present study, we used Heide and Miner's (1992) proposal to operationalize cooperation. A search of scientific databases indicated that these researchers' article was cited in more than 800 studies about cooperation or collaboration between organizations. Heide and Miner's scale has also been successfully used in Brazilian Portuguese (Hashiba, 2006).

\section{Operational Performance}

Organizational performance is widely recognized as an important - if not the most important - construct in strategy research (Combs, Crook \& Shook, 2005). In fact, the emphasis on company performance is one of the elements that distinguish this field from the other areas of organizational studies (Glick, Washburn \& Muller, 2005).

According to Venkatraman and Ramanujam (1986), financial performance and operational performance are the main indicators of company effectiveness. In their view, whereas the financial domain includes performance indicators such as sales growth, profitability and share gains, the operational domain is associated with performance indicators such as market share, the introduction of new products, product quality, and valueadded manufacturing. However, the ways of measuring company performance can vary significantly.

Combs et al. (2005) analyzed 374 articles published in the Strategic Management Journal (SMJ) from 1980 to
2004 and found 56 different performance indicators, 33 of which were related to financial performance and the remainder to operational performance. This plurality of indicators suggests that company performance is a multidimensional construct (Combs et al., 2005), although some researchers still present the construct through one single indicator (Murphy, Trailer \& Hill, 1996; Glick et al., 2005).

Despite the consensus on the need to use non-financial performance measures, there seems to be little consensus, if any, on which measures to use. This is partly because each company must obviously adopt measures that are relevant to its own particular situation. However, a common base for selecting performance measures would be valuable, not only because it would prevent measures from proliferating unnecessarily, but also ensure the correct measurement of important variables (Neely, Richards, Mills, Platts \& Bourne, 1997).

According to Roth and Miller (1992) operational strategy is associated with the following three performance measures: (1) relative manufacturing capabilities, including the operation's strength measures compared to its main competitors in terms of quality, trustworthiness, costs, flexibility, and delivery speed; (2) relative managerial success, including the ability of the company's executive body to use operational capabilities and other functional areas to achieve business goals; and (3) economic performance, such as absolute results for the business unit, including return on assets (ROA) and profitability.

Relative manufacturing capabilities (e.g., quality, trustworthiness, costs, flexibility, and speed) are classic operational performance goals that companies use to establish their competitive priorities in relation to the market (Boyer \& Lewis, 2002).

Recent decades have seen the emergence of a structure related to the content of operational strategy that has achieved relative consensus. Most researchers have begun to view operational strategy through the relative weight of the company's manufacturing capabilities, including low cost, quality, flexibility, trustworthiness, and delivery speed.

Similarly, there is a consensus that the effectiveness of an operational strategy is determined by the degree of consistency between the competitive priorities emphasized and the corresponding decisions relating to operational structure and infrastructure. Ensuring that business practices are suitable with 
regard to the company's competitive priorities is crucial for the development of operations as a source of competitive advantage (Boyer \& Lewis, 2002). In this respect, some studies in the current decade have sought to understand the role that the development of competences and capabilities in operations must play in the performance of organizations, primarily in operational performance, such as Alolayyan, Mohd All and Fazli (2011), Duarte, Brito, Di Serio, Martins (2011) and Brown, Squire and Lewis (2010).

Although operational strategy is a topic of significant interest, White (1996) acknowledges that in business and academic environments, the structuring of operational performance measures remains far from the necessary consensus between interested parties to improve business performance systems. In a thor- ough literature review, White (1996) identified 125 operational performance indicators, and organized them into the following five performance objectives relevant to the proposed system: costs, quality, delivery speed, trust in the delivery, and flexibility.

Among the dozens of indicators found for each performance objective, some are exemplified in Figure 2 in the research methods section of this paper. Most of these indicators are subjective, i.e., they indicate the manager's perception of company development compared to the main competitors. In this study, operational performance was measured as a multidimensional construct based on the performance objectives proposed by White (1996). The indicators presented in Exhibit 1 were chosen for the purposes of this study.

Exhibit 1. Operational Performance Indicators Used in this Research

\begin{tabular}{l|l}
\multicolumn{1}{c|}{ Flexibility Indicators } & \multicolumn{1}{c}{ Quality Indicators } \\
\hline Flexibility to change size/scope of orders & Compliance with product/service specifications \\
\hline Flexibility to accept program modifications & Customer complaints \\
\hline $\begin{array}{l}\text { Flexibility to introduce modifications in current } \\
\text { products/services }\end{array}$ & Products returned \\
\hline Flexibility to customize products/services & Customer satisfaction \\
\hline Velocity Indicators & Cost Indicators \\
\hline Average lead time of products/services & Losses during production/service fulfilment \\
\hline Fulfilment of promised deadlines & Product/service cost \\
\hline Production cycle time & Inventory and workforce turnover \\
\hline Fulfilment of products/services program & Productivity \\
\hline
\end{tabular}

Source: Adapted from White (1996)

Based on a subjective analysis, the research team chose operational performance indicators that could be used in as many industrial sectors as possible. The indicators chosen for each operational performance construct have not been applied to other studies, therefore, external validation is still required to make generalizations about the results.

\section{RESEARCH METHODS}

This descriptive study aims to examine the relationship between subjective uncertainty, interorganizational cooperation, and operational performance, considering the extent to which a manager's perception of uncertainty can influence cooperative behavior 
in interorganizational relations and how this behavior affects the company's operational performance.

The unit of analysis adopted for this study is the organizational relationship between managers as individuals. Dyer and Singh (1998) suggest that a company's critical resources can extend beyond its limits and may be embedded in other companies' resources and routines; thus, one important unit of analysis for understanding competitive advantage is the relationship between companies - they are potential sources of interorganizational competitive advantage.

The starting point for defining each research construct and correctly selecting indicators as proxies for measurement were the studies indicated in the theoretical references. With regard to non-objective measurements, the research data were gathered using a structured questionnaire consisting of the fol- lowing three phases: content specification, selection, and refinement of selected indicators, in line with psychometric theory for designing the scales (Diamantopoulos \& Winklhofer, 2001).

We measured the cooperation variable using a tool based on Heide and Miner (1992), whose research with a Brazilian sample was validated by Hashiba (2008) and confirmed by CFA in this study.

CFA presented a good fit regarding the four dimensions and the 14 indicators proposed by Heide and Miner (1992). However, according to covariance and modification index analyses, item "coflex 4" did not produce a good fit and was removed from the model. As a result, the second model's indices presented an excellent fit. For verification purposes, we used fit indices, residual evaluation, and modification indices (Kline, 1995), as shown in Table 1.

Table 1. Cooperation Confirmatory Factor Analysis Indices

\begin{tabular}{lccc}
$\begin{array}{l}\text { CFA } \\
\text { Result (default method) }\end{array}$ & All items & $\begin{array}{c}\text { Cooperation } \\
\text { Without coflex4 }\end{array}$ & Expected \\
\hline \hline $\begin{array}{l}\chi^{2}(\text { chi-squared) } \\
D \text { f (degrees offreedom) }\end{array}$ & 91.3 & $\mathbf{6 9 . 2}$ & "Minimum was achieved" \\
\hline$\chi^{2} / d f$ & 59 & $\mathbf{4 8}$ & $<3.0$ \\
\hline p-2alue & 1.55 & $\mathbf{1 . 4 4}$ & $>0.05$ \\
\hline Model Fit Summary & 0.004 & $\mathbf{0 . 0 2 4}$ & \\
\hline SRMR & & & $<0.01$ \\
\hline GFI & 0.119 & $\mathbf{0 . 1 0 9}$ & $>0.9$ \\
\hline AGFI & 0.937 & $\mathbf{0 . 9 4 7}$ & $>0.9$ \\
\hline CFI & 0.903 & $\mathbf{0 . 9 1 4}$ & $>0.90$ \\
\hline RMSEA (or RMS) & 0.952 & $\mathbf{0 . 9 6 6}$ & $<0.089$ \\
RMSEA (LO 90) & 0.005 & $\mathbf{0 . 0 4 5}$ & $<0.050$ \\
RMSEA (HI 90) & 0.028 & $\mathbf{0 . 0 1 7}$ & $<0.100$ \\
\hline AIC & 0.069 & $\mathbf{0 . 0 6 7}$ & \\
AIC sat. model & 155.3 & $\mathbf{1 2 9 . 1 5}$ & $<$ saturated and \\
AIC indep. model & 182.0 & $\mathbf{1 5 6 . 0 0}$ & independence models \\
\hline
\end{tabular}

Source: Derived by the authors

Subjective uncertainty was measured according to Sambiase-Lombardi and Brito (2010), who define the concept in three dimensions as suggested by Milliken (1987). Milliken focuses on the individual's perceived inability to predict an event occurring in the external environment and describes the following three dimensions of uncertainty: uncertainty of state, effect, and response. Finally, we measured the operational performance construct according to White's proposal (1996). White identified 125 operational performance indicators and organized them in five performance objectives relevant to the proposed system: costs, quality, speed, trust in the delivery, and flexibility.

In addition to the steps involved in measuring the constructs, our research tool included sections which describe the companies and respondents. The final questionnaire was sent to respondents via the Internet, using the Survey Monkey software.

The latent nature of each research construct and the relationships outlined between them simul- 
taneously involve interdependence relationships between the indicators and dependence relationships between the constructs, as shown in Figure 1. Data were analyzed using the SEM technique, which allows accessing the information subjacent to the replies and simultaneously estimating mul- tiple dependence relationships between latent variables, particularly when such variables influence a relationship (i.e., exogenous variables) and are influenced in subsequent relationships (i.e., endogenous variables) (Favero et al., 2009).

Figure 1: Theoretical model of reference

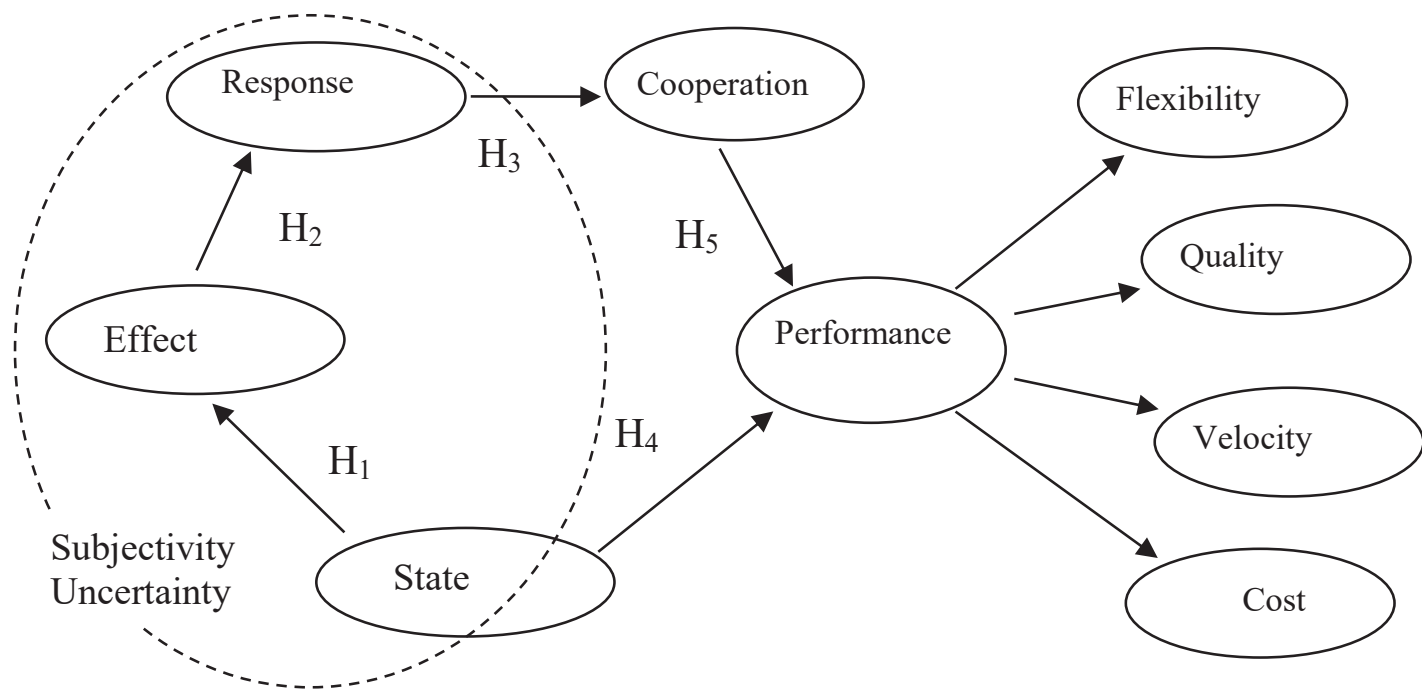

Source: Derived by the authors

One of the required assumptions in SEM processing using the ML method is the normal multivariate distribution of indicators, which can be tested by the multivariate kurtosis index measured by Mardia's PK statistic (Mardia, 1970). This statistic is asymptotically distributed as normal N (0.1); therefore, a sample can be considered normally distributed at the $5 \%$ significance level when the multivariate kurtosis standard values are lower than the critical level of 1.96. However, values above 3 for Mardia-based Kappa's normalized estimate produce low error estimates and inflate the chi-squared statistic, resulting in low significance levels $(\operatorname{sig} \leq \alpha)$ and the rejection of fitted models (Bentler $\& \mathrm{Wu}, 2002$ ).

The statistical modelling of data derived from ordinal scales with a minimum of five categories and approximately normal distributions can be performed using the ML method as if continuous without a significant distortion to levels of fit (Finney \& Di Stefano, 2006; Bollen, 1989; Muthén \& Kaplan, 1985). However, some degree of non-normality is introduced to the distribution because of the discrete nature of data. In such situations, Finney and Di Stefano (2006) recommend the use of the robust ML method, available in the EQS 6.1 software, which generates the Satorra-Bentler scaled chi-squared (SBx2) statistic. This statistic minimizes the effects of the non-normality of the distribution and complexity of the model and its fit. Furthermore, this statistic produces reliable and equally stable statistics when the sample is relatively small (Hu \& Bentler, 1995).

The following statistical tools were used to evaluate model fit: the chi-squared statistic, an index of absolute fit (the root mean square error of approximation, RMSEA), and incremental and comparative indices, including the comparative fit index (CFI), incremental fit index (IFI), and non-normed fit index (NNFI), which are relatively less affected by sample size and model complexity (Fan, Thompson \& Wang, 1999; Gerbing \& Anderson, 1993; Hu \& Bentler, 1995). In line with these authors, our study adopts magnitude references to indicate good model fit via comparative indices (CFI, IFI, NNFI $\geq 0.90)$ and the index of absolute fit $(\mathrm{RMSEA} \leq 0.08)$.

The regression coefficient significances of the structural model are evaluated using a Wald test (W test), whose null hypothesis determines that the estimated value of a parameter does not differ from zero in the population. 


\section{RESULTS AND DISCUSSIONS}

We analyzed the collected data using the SPSS software. A descriptive analysis of the data in a sample of 227 respondents revealed two influential cases, resulting in a valid sample of 225 respondents, 85\% of which are male. With regard to education, $78.4 \%$ of the respondents have a higher education or postgraduation degree, $65 \%$ are aged 31 to 50 , and $68.3 \%$ work in medium or large companies (of these, 58\% work at management level or higher).

The multivariate normality test produced by EQS 6.1 resulted in Mardia's PK normalized multivariate kurtosis statistic $(\mathrm{PK}=13.62)$ and Mardia-based Kappa (PK-based $=0.0659)$. Considering the deviation of normality shown by these results and the fact that data were derived from ordinal scales, the robust ML method was adopted in modelling the sample.

Data analysis with pre-defined relationships in the theoretical model did not result in good fit regarding the Satorra-Bentler chi-squared statistic $(\mathrm{SBx} 2=917.78 ; \mathrm{gl}=647 ; \mathrm{sig}=0.000)$. However, the values obtained for the index of absolute fit (RMSEA $=0.043$; IC $90 \%=0.037$ to 0.049 ) and the comparative and incremental indices (NNFI=0.902; $\mathrm{CFI}=0.909$; IFI=0.911) were within the limits proposed in the SEM literature. The CFI index indicated that $90.9 \%$ of the data covariance can be replicated in the population via the theoretical model proposed by Fan et al. (1999). The measurement model's factor loadings and the structural coefficients generated in the processing of data are illustrated in Figure 2.

Figure 2: Complete model structural and factor loadings

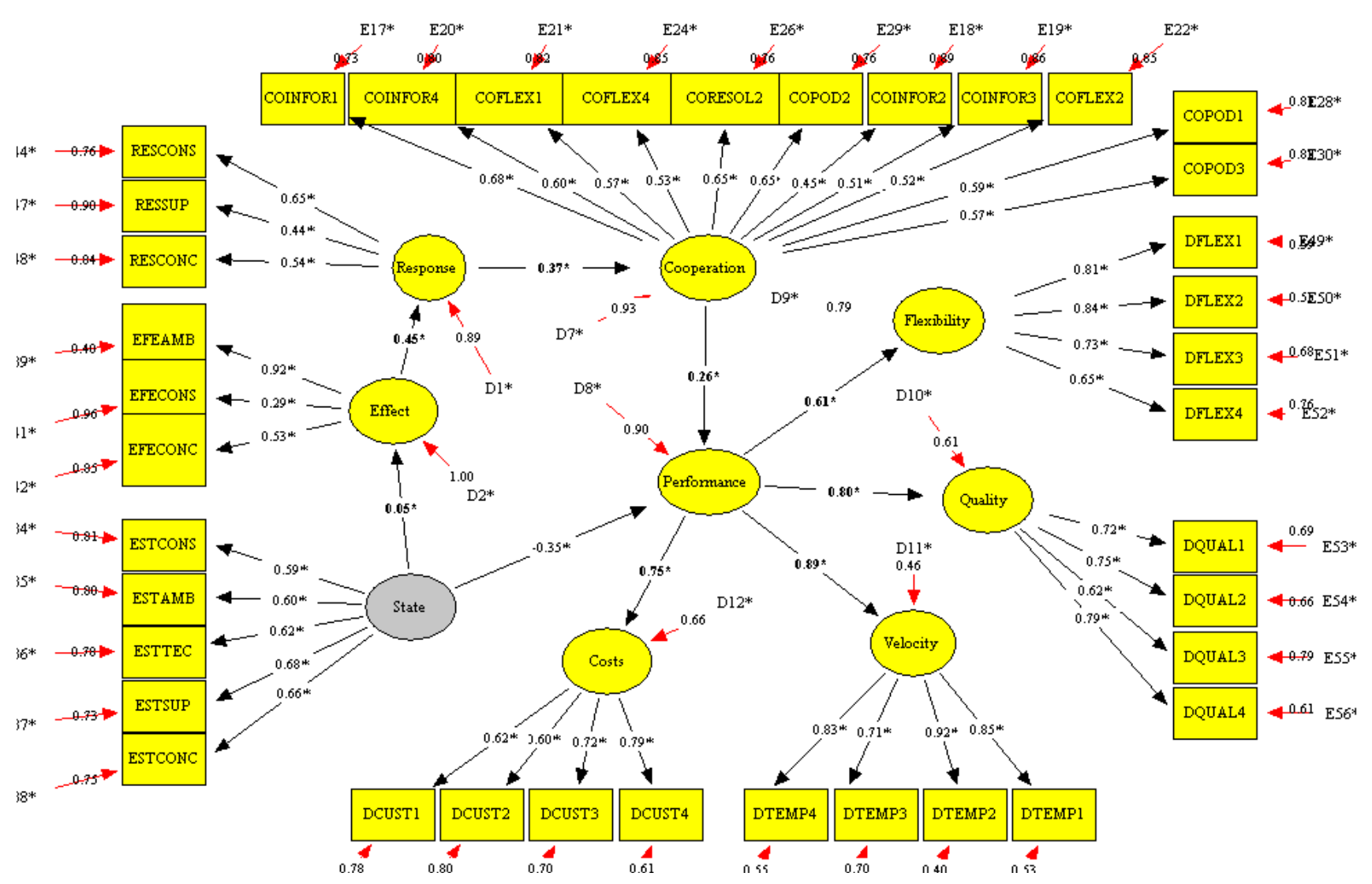

Source: Derived by the authors

The statistical significance of the structural coefficients summarized in Table 2 indicates that, at the 5\% significance level, all coefficients generated in data processing differ significantly from zero, except for the structural coefficient between state uncertainty and effect uncertainty $(~(=0.0543 ;$ sig $=0.2732)$. This result indicates that only the relationship proposed in Hypothesis 1 was not supported, i.e., state uncertainty does not significantly influence effect uncertainty. This can be explained by Milliken's defini- 
tion of the multidimensionality of the uncertainty construct (Milliken, 1987), which places the origin of uncertainty in the external environment (i.e., the environment outside the organization) and in the manager's inability to perceive and interpret the environment. The fact that state uncertainty refers to the manager's ability to perceive change in the envi- ronment and that effect uncertainty is the manager's ability to understand how such change will affect the company means that both types of uncertainty are within the scope of an individual manager's cognitive mental processes. This makes it more difficult to measure these factors using a more generic data collection tool, as was the case in this study.

Table 2: Standardized coefficients of the structural model

\begin{tabular}{l|c|c|c|c|l}
\hline Structural relationships & Coef. & "t" Student & Sig. & $\mathbf{R}^{\mathbf{2}}$ & Test results \\
\hline H1: State $\rightarrow$ Effect & 0.0543 & 0.6031 & 0.2732 & 0.0029 & Not Supported \\
\hline H2: Effect $\rightarrow$ Response & 0.4522 & 4.3939 & 0.0000 & 0.2045 & Supported \\
\hline H3: Response $\rightarrow$ Cooperation & 0.3657 & 3.6939 & 0.0001 & 0.1337 & Supported \\
\hline H4: State $\rightarrow$ Performance & -0.3458 & -4.2857 & 0.0006 & \multirow{2}{*}{0.1851} & Supported \\
\cline { 1 - 4 } H5: Cooperation $\rightarrow$ Performance & 0.2560 & 3.2303 & 0.0000 & & Supported \\
\hline
\end{tabular}

Source: Derived by the authors based on the research data

Table 2 also includes the coefficient of determination $\left(\mathrm{R}^{2}\right)$ values produced during the analysis. Effect uncertainty has a significant influence on response uncertainty: $20.45 \%$ of the response uncertainty's variability is explained by effect uncertainty. Since effect uncertainty is the manager's ability to understand how change in the external environment will affect the company, and response uncertainty relates to the manager's actions in response to external environment changes (Milliken, 1987), the confirmation of Hypothesis 2 can be explained by the proximity of effect uncertainty to the tangible actions and policies chosen by the manager during the decision process, which allows measuring part of this relationship.

The same finding can be seen with regard to cooperation, with $13.37 \%$ of its variation explained by response uncertainty, thus confirming Hypothesis 3. This relationship is described in the literature by Knight (2006), Williamson (1975), Dess and Beard (1984), Shervani et al. (2007) and others. These authors suggest that interorganizational cooperation can be encouraged by external environment uncertainty, wherein ambiguous objectives and uncertainty about the future prompt firms to form alliances (Das \& Teng, 1998). Uncertainty influences the executive's ability to make business decisions because the difficulty lies in establishing scenarios; in the face of subjective probability or non-measurable uncertainty, a set of possible actions can be more effectively devised by a group than individually (Duncan, 1972; Huff, 1978; Milliken, 1987).
The confirmation of Hypothesis 4 regarding the influence of state uncertainty on operational performance, with an explanation of $18.51 \%$, corroborates profit theory (Knight, 2006) and affirms the manager's role according to his/her ability to make correct judgments in unique situations. It is this ability that makes a human being useful in business (Duncan, 1972; Huff, 1978; Milliken, 1987).

Hypothesis 5 tested the operational performance variance in interorganizational relationships, and $18.51 \%$ of variance was explained. Cooperative relationships, whether formal or informal, can determine the contribution of different parties to organizational outcomes (Smith et al., 1995); such a contribution or cooperation is defined in exchange theories as a means of maximizing economical and psychological benefits (Blau, 1974). Nalebuff and Brandenburger (1996) suggest that interdependence between parties is of central importance to understand business and operational performance through the idea of complementarity, alongside competitive price mechanisms (Fehr \& Schmidt, 1999).

\section{CONCLUSIONS}

Compared to companies in other continents, Latin American companies are significantly more likely to avoid uncertainties (Lo, Waters, \& Christensen, 2017). In the context of this paper, results suggest that the level of rejection to uncertainty may be the cause of the long known, frequent short-term orien- 
tation in regional firms, generating a vicious cycle of instability in many organizations. Entrepreneurs and managers who participated in this study showed that understanding the effects of uncertainty on the company and taking the right managerial actions to deal with it have a relevant effect on operational performance, as well as on cooperation among companies.

Uncertainty is an abstract concept that is complex to measure. Its multidimensional nature allowed this study to reach the conclusion that, when it comes to cooperation, the most important dimension of subjective uncertainty is uncertainty of state, since this dimension represents actions that are visible to interorganizational relationships (a manager's response during the decision-making process is expressed through his actions or policies). Such finding may contribute to take further steps in this research theme.

In view of the importance of interorganizational relationships for operational performance (Dyer, 1997), this study proved that cooperation influences business operational performance. This result corroborates the relational view, which maintains that the relationship between network participants is critical to the success of a business. This theoretical perspective focuses on network routines/practices and processes as an important unit of analysis for understanding a company's superior performance (Dyer \& Singh, 1998).

Since uncertainty and cooperation have an intrinsic relationship and given the fact that Latin American firms are more sensitive to uncertainty, future research could focus on understanding how uncertainty affects the willingness of regional companies to broaden the cooperation among firms, especially those belonging to the same supply chain. Evidence regarding this issue is scarce and usually anecdotal in the region. It is worth mentioning that the advantages and disadvantages of an individual firm are frequently related to the advantages and disadvantages of the network of relationships to which that firm belongs (Dyer \& Singh, 1998).

In profit theory, Knight (2006) argues that the connection between change and profit is uncertain and always indirect, suggesting that uncertainty is the indirect connection between change and profit. This study found that, when state uncertainty influences operational performance, this dimension of uncertainty captures the portion of uncertainty relating to the individual's perception of uncertainty and his rationality (Simon, 1983), as well as the portion of uncertainty relating to the environment. The latter portion is associated with turbulent events in the macro-environment and/or the complexity and dynamism of the section of the environment the company is situated in.

Evidence that information available or believed to be available to a manager affects operational performance has a strong managerial implication. Such finding can be interpreted as a warning against the malicious effects of "hiding info", usual in Latin American firms. Many of them are not keen on sharing relevant information upstream or downstream a supply chain, a behavior that limits the potential for superior performance.

The findings of this research, however, cannot be generalized for reasons of scope (limited to Brazilian firms) and probabilistic issues. Nevertheless, possibilities for future research are wide, ranging from understanding the relationship between uncertainty and cooperation in Latin American firms to taking a supply chain perspective to how uncertainty, cooperation and operational performance relate to one another. Future studies could also use a more qualitative approach to understand the relationship between state and effect uncertainties, focusing on each manager's environment and specific interorganizational relationships. It is clear that operational performance depends on more variables than the ones encompassed by the construct proposed in this study, and a qualitative focus could be very helpful in deepening its comprehension.

When it comes to performance, the shift from perceptual scales to real, measurable operational indicators could mean an enormous breakthrough for the Operations Management field. In a Latin American context, getting such numbers would sound miraculous, given the natural resistance of regional entrepreneurs to disclosing their results.

\section{REFERENCES}

Alolayyan, M. N., Mohd All, K. A., \& Fazli, I. (2011) The impact of operational flexibility on hospital performance in Jordanian hospitals: Some empirical evidences. Journal of Global Management, 2(1), 39-52.

Ashill, N. J., \& Jobber, D. (2009). Measuring state, effect, and response uncertainty: Theoretical construct development and empirical validation. Journal of Management, 36(5), 1278-1308. doi:10.1177/0149206308329968.

Barnard, C. I. (1938). The functions of the executive. Boston: Harvard University Press. 
Bello, A. (2017). Latin America's disappointing economic growth: The commodity hangover has been compounded by political uncertainty. Retrieved from https://www.economist. $\mathrm{com} /$ news/americas/21725344-commodity-hangover-hasbeen-compounded-political-uncertainty-latin-americas-disappointing.

Bentler, P. M., \& Wu, E. J. C. (2002). EQS 6 for Windows guide. Encino, CA: Multivariate Software.

Blau, P. (1974). Presidential address: Parameters of Social Structure. American Sociological Review, 39(5), 615-635.

Bollen, K. A. (1989). Structural equations with latent variables. New York: Wiley.

Boyer, K. K., \& Lewis, M. W. (2002). Competitive priorities: Investigating the need for trade-offs in operations strategy. Production and Operations Management, 11(1), 9-20. doi:10.1111/j.1937-5956.2002.tb00181.x.

Bradach J. L.\& Eccles, R. G. (1989). Price, authority and trust: From ideal parts to plural forms. Annual Review from Sociology, 15, 97-118. doi:https://doi.org/10.1146/annurev. so.15.080189.000525.

Brito, E. P. Z., \& Mariotto, G. (2013). Benefits of cooperation between buyers and provides: A study in the field of information and communications technology. Revista Brasileira de Gestão de Negócios, 15(47), 241-261. doi:10.7819/rbgn. v15i47.1354

Brown S., Squire B., \& Lewis M. (2010). The impact of inclusive and fragmented operations strategy processes on operational performance. International Journal of Production Research, 48(14), 4179-4198.

Cheng, J. H., \& Tang, C. H. (2014). Interorganizational cooperation and supply chain performance in the context of third party logistics services. Asia Pacific Management Review, 19(4) 375-390. doi:10.6126/APMR.2014.19.4.03.

Choi, C., Lee, S., \& Kim, J. (1999). A note on countertrade: Contractual uncertainty and transaction governance in emerging economies. Journal of International Business Studies, 30(1), 189-201.

Coase, R. H. (1993). The nature of the firm (1937), In O. Williamson, S. G. Winter (Org.). The nature of the firm: Origins, evolution, and development. Oxford: Oxford University Press.

Combs, J. G., Crook, T. R., \& Shook, C. L. (2005). The dimensionality of organizational performance and its implications for strategic management research, In D. J. Ketchen \& D. D. Bergh (Eds.) Research Methodology in Strategy and Management, 2(5), 259-286. doi:10.1016/S1479-8387(05)02011-4.

Contractor, F. J., \& Lorange, P. (1988). Why should firms cooperate? The strategy and economic basis for cooperative ventures, In F. J. Contractor, \& M. Lorange (Eds), Cooperative Strategies in International Business, Lexington Books, Lexington, MA, pp. 3-38.

Das, T. K., \& Teng, B.-S. (2001), Strategic risk behaviour and its temporalities: Between risk propensity and decision context. Journal of Management Studies, 38, 515-534. doi:10.1111/1467-6486.00247

Dess, G. G., \& Beard, D. W. (1984). Dimensions of organizational task environments. Administrative Science Quarterly, 29(1), 52-73. doi:10.2307/2393080.

Diamantopoulos, A., \& Winklhofer, H. M. (2001). Index construction with formative indicators: An alternative to scale development. Journal of Marketing Research, 38(2), 269-277. doi:10.1509/jmkr.38.2.269.18845.

Doz, Y. L. (1996). The evolution of cooperation in strategic alliances: Initial conditions or learning processes? Strategic Management Journal, 17, 55-83. doi:10.1002/ smj.4250171006

Duarte, A. L. C. M., Brito, L. A. L., Di Serio, L. C., \&"Martins, G. S. (2011). Operational practices and financial performance: An empirical analysis of Brazilian manufacturing companies. BAR-Brazilian Administration Review, 8(4), 395-411.

Duncan, R. B. (1972). Characteristics of organizational environments and perceived environmental uncertainty. Administrative Science Quarterly, 17(3), 313-332. doi:10.2307/2392145.

Dyer, J. H. (1996). Specialized supplier networks as a source of competitive advantage: Evidence from the auto industry. Strategic Management Journal, 17(4), 271-291. doi:10.1002/(SICI)1097-0266(199604)17:4<271::AIDSMJ807>3.0.CO;2-Y

Dyer, J. H. (1997). Effective inter-firm collaboration: How firms minimize transaction costs and maximize transaction value. Strategic Management Journal. 18(7), 535-556. doi:10.12691/jfe-2-5-9.

Dyer, J. H., \& Singh, H. (1998). The relational view: Cooperative strategy and sources of interorganizational competitive advantage. Academy of Management Review, 23(4), 660-679. doi:10.5465/AMR.1998.1255632.

Dyer, J. H., Kale, P., \& Singh, H. (2001). Strategic alliances work. MIT Sloan Management Review. Retrieved from http:// sloanreview.mit.edu/

Economic Commission for Latin America and the Caribbean. Economic survey of Latin America and the Caribbean 2017: Dynamics of the current economic cycle and policy challenges for boosting investment and growth. Retrieved from http:// repositorio.cepal.org/bitstream/handle/11362/42002/18/ EEI2017_Brasil_en.pdf.

Fan, X., Thompson, \& B., Wang, L. (1999). Effects of sample size, estimation method, and model specification on structural equation modeling fit indexes. Structural Equation Modeling (6), 56-83. doi:10.1080/10705519909540119.

Favero, L. P., Belfiore, P., Silva, F. L. \& Chan, B. L. (2009). Análise de dados: Modelagem multivariada para tomada de decisões. Rio de Janeiro: Elsevier.

Fehr, E., \& Schmidt, K. M. A. (1999). Theory of fairness, competition, and cooperation. The Quarterly Journal of Economics, 114(3), 817-868. doi:10.1162/003355399556151 
Finney, S. J., \& DiStefano, C. (2006). Non-normal and categorical data in structural equation modeling. In G. R. Hancock \& R. O. Mueller (Eds.), Structural equation modeling: A second course. Greenwich, CT: Information Age Publishing.

Foss, N. J. (1996). More critical comments on knowledgebased theories of the firm. Organization Science, 7(5), 519523. doi:10.1287/orsc.7.5.519.

Gao, T., Sirgyb, M. J., \& Birdb, M. M. (2005). Reducing buyer decision-making uncertainty in organizational purchasing: Can supplier trust, commitment, and dependence help? Journal of Business Research,58(4), 397-405. doi:10.1016/ S0148-2963(03)00137-1.

Gerbing, D. W., \& Anderson, J. C. (1993). Monte Carlo evaluations of goodness-of-fit indices for structural equation models. In K. A. Bollen, \& J. S. Long (Eds.), Testing structural equation models. Newbury Park, CA: Sage.

Ghosh, S., Bhowmick, B., \& Guin, K. K. (2014). Perceived Environmental Uncertainty for Startups: A Note on Entrepreneurship Research from an Indian Perspective. Technology Innovation Management Review, 4(8): 27-35. http://timreview.ca/article/820.

Glick, W. H., Washburn, N. T., \& Muller, C. C. (2005). The myth of firm performance. Annual Meeting of American Academy of Management (pp. 1-28). Honolulu: Academy of Management Review.

González, M., Guzmán, A., Téllez, D., Trujillo, M-A, (2016). What do you say and how do you say it: Information disclosure in Latin American firms. Center for Research in Economics and Finance (CIEF), Working Papers, No. 17-05. doi:10.2139/ssrn.2929833.

Hashiba, L. (2008). O relacionamento colaborativo com fornecedores e clientes e sua influência no desempenho da firma: Uma análise empírica na indústria brasileira de embalagens. São Paulo. 198 f. Dissertação Mestrado em Administração de Empresas - EAESP, Fundação Getúlio Vargas.

Heide, J. B., \& Miner, A. S. (1992). The shadow of the future: Effects of anticipated interactions and frequency of contact on buyer-seller cooperation. Academy of Management Journal, 35(2), 265-291. doi:10.2307/256374.

Heide, J. B., \& Stump, R. L. (1995). Performance implications of buyer-supplier relationships in industrial markets: A transaction cost explanation. Journal of Business Research, 32(1), 57-66. doi:10.1016/0148-2963(94)00010-C.

Hu, L.T., \& Bentler, P. (1995). Evaluating model fit. In R. H. Hoyle (Ed.), Structural Equation Modeling. Concepts, Issues, and Applications (pp. 76-99). London: Sage.

Huff, A. S. (1978). Consensual uncertainty. Academy of Management Review, 25(1), 651-655. doi:10.5465/ amr.1978.4305928.

Johnson, D., \& López-Alves, F. (Eds.). (2007). Globalization and uncertainty in Latin America. London: Palgrave Macmillan. Kaplan, R., \& Norton, D. (1996). Balanced scorecard: Strategy into action. Harvard Business School Press.

Kline, R. B. (1995). Principles and practice of structural equation modeling. 2 ed. New York: Guilford Press.
Knight, F. H. (2006). Risk, uncertainty and profit. Washington: Beard Books.

Kreiser, P., \& Marino, L. (2002). Analyzing the historical development of the environmental uncertainty construct. Management Decision, 40(9), 895-905. doi:10.1108/00251740210441090.

Lawrence, P. R., \& Lorsch, J. W. (1967). Organization and environment: Managing differentiation and integration. Boston: Harvard University Press.

Langlois, R. N., \& Cosgel, M. M. (1993). Frank Knight on risk, uncertainty, and the firm: A new interpretation. Economic inquiry, 31(3), 456-465. doi:10.1111/j.1465-7295.1993.tb01305.x

LeRoy, S. F., \& Singell, L. D. (1987). Knight on risk and uncertainty. The Journal of Political Economy, 95(2), 394-406. doi:10.1086/261461

Lo, K. D., Waters, R. D., \& Christensen, N. (2017). Assessing the applicability of Hofstede's cultural dimensions for Global 500 corporations' Facebook profiles and content. Journal of Communication Management, 21(1), 51-67.doi:10.1108/ JCOM-04-2016-0021

Luce, R. D., \& Raiffa, H. (2013). Games and decisions: Introduction and critical survey. Originally published: New York: Wiley

Lueg, R., \& Borisov, B. G. (2014). Archival or perceived measures of environmental uncertainty? Conceptualization and new empirical evidence. European Management Journal, 32(2014) 658-671. doi:10.1016/j.emj.2013.11.004

Mardia, K. V. (1970). Measures of multivariate skewness and kurtosis with applications. Biometrika, 57(3), 519-530. doi: $10.2307 / 2334770$

Macneil, I. R. (1981). Economic analysis of contractual relations: Its shortfalls and the need for a rich classificatory apparatus. Northwestern Law Review, 75(6), 1018-1063.

Miles, G., Snow, C. C., \& Sharfman, M. P. (1993). Industry variety and performance. Strategic Management Journal, 14(3), 163-177. doi:10.1002/ smj.4250140302

Milliken, F. J. (1987). Three types of perceived uncertainty about the environment: State, effect, and response uncertainty. The Academy of Management Review, 12(1), 133-143. doi:10.5465/AMR.1987.4306502

Milliken, F. J. (1990). Perceiving and interpreting environmental change: An examination of college administrators' interpretation of changing demographics. The Academy of Management Journal, 33(1), 42-63. doi:10.2307/256351

Murphy, G. B., Trailer, J. W., \& Hill, R. C. (1996). Measuring performance in entrepreneurship research. Journal of Business Research, 36(1), 15-23. doi:10.1016/01482963(95)00159-X.

Muthén, B., \& Kaplan D. D. (1985). A comparison of methodologies for the factor analysis of non-normal Likert variables. British Journal of Mathematical and Statistical Psychology, Vol. 38, No. 1, pp. 171-189. doi: 10.1111/ j.2044-8317.1992.tb00975.x 
Nalebuff, B., \& Brandenburger, A. (1996). Co-opetição: Um conceito revolucionário que combina competição com cooperação, 2. A estratégia da teoria do jogo que está mudando o jogo dos negócios. Rio de Janeiro: Rocco.

Nguyen, A. \& Cragg, W. (2012). Interorganizational favour exchange and the relationship between doing well and doing good. Journal of Business Ethics, 105(1), 53-68. doi:10.1007/ s10551-011-0947-1.

Neely, A., Richards, H., Mills, J., Platts, K., \& Bourne, M. (1997). Designing performance measures: A structured approach. International JournalofOperations \& ProductionManagement, 17(11), 1131-1152. doi:10.1108/01443579710177888.

Parkhe, A. (1993). Strategic alliance structuring: A game theoretic and transaction cost examination of interfirm cooperation. Academy of Management Journal, 36(August), 794829. doi: $10.2307 / 256759$

Pfeffer, J., \& Salancik, G. R. (1977). Organization design: The case for a coalitional model of organizations. Organizational Dynamics, 6(2), 15-29. doi:10.1016/00902616(77)90043-2

Ring, P. S., \& Van De Ven, A. H. (1994). Developmental processes of cooperative interorganizational relationships. Academy of Management Review, 19(1), 90-118. doi:10.2307/258836

Roth, A. V., \& Miller, J. G. (1992). Success factors in manufacturing. Business Horizons, 35(4), 73-81. doi:10.1016/ S0007-6813(05)80165-X

Sadler, M. (2017). Has Brazil's GDP risen despite political uncertainty in 1Q17? Retrieved from http://marketrealist. com/2017/06/has-brazils-gdp-risen-despite-political-uncertainty-in-1q17/.

Sambiase-Lombardi, M. F., \& Brito, E. Z. P. (2004). Cooperação entre empresas de tecnologia de informação: um estudo de fatores que contribuem para sua continuidade. In: Encontro De Estudos Organizacionais - ENEO, 2004, Atibaia SP. Anais... ENEO.

Sambiase-Lombardi, M. F., \& Brito, E. P. Z. (2010). Incerteza subjetiva no processo de decisão estratégica: Uma proposta de mensuração. Revista de Administração Contemporânea, Curitiba, 14(6), 990-1010.

Satorra, A., \& Bentler, P. M. (2001). A scaled difference chisquare test statistic for moment structure analysis. Psychometrika, 66(4), 507-514. doi:10.1007/BF02296192

Shervani, T. A., Frazier, G., \& Challagalla, G. (2007). The moderating influence of firm market power on the transaction cost economics model: An empirical test in a forward channel integration context. Strategic Management Journal, 28(6), 635-52. doi:10.1002/smj.585

Simon, H. A. (1983). Models of Bounded Rationality. Cambridge, MA: The MIT Press.
Smith, K. G., Carrol, S. J., \& Ashford, S. J. (1995). Intra- and inter-organizational cooperation: Toward a research agenda. Academy of Management Journal, 38(1), 7-23. doi:10.2307/256726

Snow, C. C., Fjeldstad, Ø. D., Lettl, C., \& Miles, R. E. (2011). Organizing continuous product development and commercialization: The collaborative community of firms model. Journal of Product Innovation Management, 28(1), 3-16. doi:10.1111/j.1540-5885.2010.00777.x

Thompson, J. D. (1967). Organization in action. New York: McGraw-Hill.

Venkatraman, N., \& Ramanujam, V. (1986). Measurement of business performance in strategy research: A comparison of approaches. Academy of Management Review, 11(4), 801814.

Vitale, D. (2016). América do Sul: Reflexões contemporâneas sobre cooperação, democracia e desenvolvimento. Caderno CRH, 29(SPE3), 9-12. doi:10.1590/S010349792016000400001

White, G. P. (1996). A survey and taxonomy of strategy-related performance measures for manufacturing. International Journal of Operations \& Production Management, 16(3), 4261. doi:10.1108/01443579610110486

White, S., \& Lui, S. S. Y. (2005). Distinguishing costs of cooperation and control in alliances. Strategic Management Journal, 26(10), 913. doi:10.1002/smj.490

Williamson, O. E. (1975). Markets and hierarchies: Analysis and antitrust implications. Nova York: Free Press.

Williamson, O. E. (1985). The mechanisms of governance. Nova York: Oxford University Press.

Williamson, O. E. (1999). Strategy research: Governance and competence perspectives. Strategic Management Journal, 20(12), 1087-1108. doi:10.1002/(sici)10970266(199912)20:12<1087::aid-smj71>3.0.co;2-z

World Economic Forum. (2017). Economic outlook for Latin America: Uncertainty and risks but with opportunities. Retrieved from https://www.weforum.org/press/2017/04/ economic-outlook-for-latin-america-uncertainty-andrisks-but-with-opportunities/.

Zajac, E. J., \& Olsen, C. P. (1993). From transaction cost to transactional values analysis: Implications for the study of interorganizational strategies. Journal of Management Studies, 30(1), 173-191. doi:10.1111/j.1467-6486.1993. tb00298.x

Zewuster, M. (2017). Latin America outlook - Uncertainty rife. Retrieved from https://insights.abnamro.nl/en/2017/01/ latin-america-outlook-uncertainty-rife/. 